\title{
Delincuencia y gubernamentalidad neoliberal en el cine chileno de la transición a la democracia*
}

\author{
Delinquency and governmentality neoliberal in the Chilean cinema \\ of the transition to democracy \\ Juan Pablo Silva-Escobar ${ }^{* *}$ \\ Valentina Raurich ${ }^{* *}$
}

\begin{abstract}
Resumen: Este artículo analiza las representaciones fílmicas de la delincuencia en el cine de la transición chilena a la democracia, poniendo atención a la relación entre discurso fílmico y contexto sociopolítico. Para ello, conceptualizamos desde una perspectiva foucaulteana la noción de gubernamentalidad, posteriormente examinamos el modo en que la transición instauró la expansión del consumo como gestión de gobierno y, finalmente, indagamos en los imaginarios sociales y las ideologías asociadas a la representación fílmica del delincuente, buscando determinar cómo se inscribe cinematográficamente la gubernamentalidad y los modos de subjetivación neoliberal. Para ello, analizaremos las películas Caluga o menta (1990) de Gonzalo Justiniano, Johnny cien pesos (1993) de Gustavo Graef Marino; Taxi para tres (2001) de Orlando Lübbert y Mala leche (2004) de León Errazuriz.
\end{abstract}

Palabras clave: Cine chileno, delincuencia, transición a la democracia, neoliberalismo

\begin{abstract}
This article analyses the filmic representations of delinquency in the cinema of the Chilean transition to democracy, paying attention to the relationship between film discourse and sociopolitical context. To do this we conceptualise, from a foucaulteana perspective, the notion of governmentality, later we examine the way in which the transition established the expansion of consumption as a way of governance and, finally, we investigate the social imaginary and ideologies associated with the filmic representation of the offender, seeking to determine how the governmentality and modes of neoliberal subjectivation are registered in four films of the chilean cinema of the transition. For this, we will analyze the films Caluga o menta (Gonzalo Justiniano, 1990), Johnny cien pesos (Gustavo Graef Marino, 1993); Taxi para tres (Orlando Lübbert, 2001) y Mala leche (León Errazuriz, 2004).
\end{abstract}

Keywords: Chilean cinema, delinquency, transition to democracy, neoliberalism

Recibido: 22 enero 2019 Aceptado: 18 marzo 2019

\footnotetext{
* Este artículo es uno de los resultados del proyecto FONDECYT N 11160133 “Cine, neoliberalismo y sociedad. Por una genealogía de la representación de la pobreza en el cine de ficción chileno (1980-2015)".

** Chileno, coautor, Dr. en Antropología de Iberoamérica (Universidad de Valladolid), Dr. en Estudios Latinoamericanos (Universidad de Chile). Académico del Centro de Investigaciones en Artes y Humanidades (CIAH), Facultad de Artes, Universidad Mayor, Chile / Centro de Estudios Históricos (CEH), Universidad Bernardo O’Higgins. E-mail juan.silvae@umayor.cl

*** Chilena, coautora, Antropóloga (Universidad de Chile), Máster-DEA en Antropología Social (Universidad de Valladolid), Dra. (c) en Antropología de Iberoamérica (Universidad de Valladolid). Investigadora Independiente. E-mail vraurichv@gmail.com
} 


\section{Introducción}

El cine como tecnología de significación implica entender la producción cinematográfica como un dispositivo complejo que involucra un conjunto de procedimientos estéticos, discusivos y técnicos. Mediante relatos, imágenes y sonidos, el cine fabrica una realidad filmica que no solo elabora y distribuye sobre el campo social narraciones que pueden ser analizadas en cuanto diégesis o narración, sino que también se constituye como texto fílmico, es decir, las películas se conforman como una red de palabras, imágenes y sonidos, dispuestos de una manera tal que asignan un sentido que ordena y encierra una totalidad significativa. ${ }^{1}$ Dentro del texto filmico, las imágenes y los discursos que en él habitan se encuentra relacionados con otros discursos, otras imágenes, otros textos y contextos, conformando un intertexto fílmico que se organiza como "un tejido nuevo de citas pasadas". ${ }^{2}$

Es a partir de la intertextualidad que los textos se dan vida entre sí y comparecen dentro del campo social, "no por la vía de una filiación identificable, de una imitación voluntaria, sino por la vía de la diseminación, una imagen que asegura al texto el estatuto, no de una reproducción, sino de una productividad". ${ }^{3} \mathrm{La}$ productividad del texto fílmico implica un trabajo de hibridación textual en la que comparecen prácticas, saberes y discursos que una vez fijados, es decir, proyectado el texto filmico, continua con su proceso de producción de sentido a través de la circulación de clasificaciones e ideologías que se expanden por el campo social y por los imaginarios, haciendo de la productividad filmica un poder simbólico, esto es, un poder capaz de "constituir lo dado por la enunciación, de hacer ver y hacer creer, de confirmar o transformar la visión del mundo y, por ello, la acción sobre el mundo, por lo tanto el mundo". ${ }^{4}$ Una de las maneras mediante las cuales el cine opera discursivamente dentro del campo social, es a partir de una distribución de sentido, donde las imágenes audiovisuales toman posición y se organizan como "una máquina gigantesca de producir el acontecimiento como signo, como valor intercambiable en el mercado universal de la ideología". 5

El cine como texto se encuentra predeterminado y hasta cierto punto prefigurado por la formación histórica a la que pertenece una determinada obra. De este modo, es posible distinguir a lo largo de la historia del cine chileno al menos seis grandes estratos de visibilidad por los que ha transitado el cine chileno desde su llegada al país: 1) cine mudo (oligarquía terrateniente); 2) cine del desarrollismo (élite y el proyecto de industrialización del país); 3) nuevo cine (lo popular como categoría política, Unidad Popular), 4) cine en dictadura (violencia política y neoliberalismo autoritario); 5) cine de la transición (democracia semisoberana, consolidación de la hegemonía neoliberal); 6) cine del neoliberalismo tardío (híperindividualización de la subjetividad, empresarización de los individuos). Siguiendo a Gilles Deleuze, estos estratos de visibilidad se establecen a partir de las distintas formaciones históricas y se constituyen como "capas sedimentarias hechas de cosas y de palabras, de ver y de hablar, de visible y de decible, de superficies de visibilidad y de campos de legibilidad, de contenidos y de expresiones". ${ }^{6}$ En tal sentido, el cine en tanto campo de visibilidad de la modernidad lleva inscrito en su productividad las condiciones de posibilidad que autorizan la aparición de determinados discursos en una época y en un momento determinado. ${ }^{7}$

\footnotetext{
${ }^{1}$ Roland Barthes, Variaciones sobre la escritura, Barcelona, Paidós, 2002.

2 Ibid., p. 146.

${ }^{3}$ Idem.

4 Pierre Bourdieu, “Sobre el poder simbólico”. En Intelectuales, política y poder. Buenos Aires: EUDEBA, 2006, p. 71.

5 Jean Baudrillard, El intercambio imposible, Madrid: Cátedra, 2000, p. 135.

${ }_{6}^{6}$ Gilles Deleuze, Foucault. Barcelona: Paidós, 1987, p. 75.

${ }^{7}$ Michel Foucault, Las palabras y las cosas. Una arqueología de las ciencias humanas. México DF: Siglo XXI Editores, 1995a.
} 
Nuestro objetivo es reflexionar acerca de las representaciones fílmicas del delincuente en el cine de la transición a la democracia, procurando pesquisar la relación entre discurso fílmico y contexto sociopolítico neoliberal. Para ello, en un primer momento, conceptualizaremos desde una perspectiva foucaulteana la noción de gubernamentalidad neoliberal y los dispositivos biopolíticos, los mecanismos de disciplinamiento y de seguridad que se desprenden de esta forma de gobierno. Posteriormente examinaremos el modo en que la transición instauró la expansión del consumo como gestión de gobierno y la consecuente sociedad de mercado que convierte y reduce lo social, lo político y lo cultural a relaciones financiarizadas. Finalmente, a partir del marco conceptual foucaulteano y del contexto sociopolítico de la transición, indagaremos en los imaginarios sociales y las ideologías asociadas a la representación fílmica del delincuente, buscando determinar cómo se inscribe cinematográficamente la gubernamentalidad y los modos de subjetivación neoliberal en el cine del período de la transición.

Conceptualmente entendemos el neoliberalismo como racionalidad, esto implica entender que no se trata solamente de una ideología de mercado, ni exclusivamente una teoría económica, ni siquiera es sólo un programa político, es mucho más que eso, es una particular forma de concebir, razonar y habitar el mundo que, de acuerdo con Christian Laval y Pierre Dardot, organiza y estructura no solo las acciones de la élite gobernante, sino también la conducta de los gobernados. "La racionalidad neoliberal tiene como característica principal la generación de la competencia como norma de conducta y de la empresa como modelo de subjetivación". ${ }^{8}$ Todo este entramado ideológico se expresa a través de procedimientos, dispositivos, técnicas, discursos, presupuestos y razonamientos que han hegemonizado no sólo la economía, sino también la cultura, la política y la sociedad a partir de un conjunto de prácticas individualizadoras, que modulan las subjetividades mediante el ejercicio práctico y estratégico del control de la conducta de la población. ${ }^{9}$ A este entramado complejo es lo que Michel Foucault llamó gubernamentalidad neoliberal y a partir de allí analizó el modo en que los dispositivos de seguridad, los mecanismos disciplinarios y la biopolítica se configuran como mecanismos y técnicas que se utilizan para gobernar y controlar las acciones y las mentalidades de la población. ${ }^{10}$

La noción de gubernamentalidad nos va a permitir caracterizar el inicio de la transición a la democracia como una gestión de gobierno centrada en un "arte de gobernar" a la población como una masa cuantificable y moldeable a partir del consumo como posibilidad de reconocimiento social. La gubernamentalidad, de acuerdo con Michel Foucault, puede ser definida como "el conjunto constituidos por las instituciones, los procedimientos, análisis y reflexiones, los cálculos y las tácticas que permiten ejercer esa forma bien específica, aunque muy compleja, de poder que tiene por blanco principal la población". ${ }^{11}$ Uno de los dispositivos clave de la gubernamentalidad neoliberal son los mecanismos de seguridad que no están centrados en el individuo, como era el caso de los dispositivos disciplinarios, sino que tratan una problemática mayor ligada al cuerpo social como pluralidad. Esta nueva técnica de poder no excluye las técnicas disciplinarias, sino más bien las envuelve, las utiliza, las transforma parcialmente, y las lleva a otro nivel, porque las técnicas de seguridad se aplican sobre el ser humano en cuanto sujeto vivo perteneciente a la especie humana y como parte de un grupo social; vale decir, si con los dispositivos disciplinarios se ejerce un poder sobre el cuerpo-individuo, con los dispositivos de seguridad se ejerce un poder sobre el cuerpo-social, sobre el sujeto-especie. Por lo tanto, Los dispositivos de seguridad ejercen un poder que ya no es individualizador sino masificador y se despliega sobre el conjunto de la población, a través de la biopolítica, que sería una técnica de poder y control que actúa sobre el conjunto de la vida de las poblaciones, de ahí que incluya una serie de procedimientos destinados a controlar, fiscalizar, vigilar

8 Christian Laval y Pierre Dardot, La nueva razón del mundo. Ensayo sobre la sociedad neoliberal. Barcelona: Gedisa, 2013, p. 15.

9 Luna Follegati y Rodrigo Karmy, "Introducción”, Luna Follegati y Rodrigo Karmy (comp.) Estudios en Gubernamentalidad. Ensayos sobre poder, vida y neoliberalismo. Viña del Mar: Asociación Comunes, 2018. pp. 17-45.

10 Michel Foucault, Nacimiento de la biopolítica, Buenos Aires: Fondo de Cultura Económica, 2016.

${ }^{11}$ Michel Foucault, Seguridad, territorio y población. Buenos Aires: Fondo de Cultura Económica, 2006, p. 136. 
e intervenir sobre aquellos aspectos de la vida, la muerte, el matrimonio, las enfermedades, la sexualidad, el crimen, entre otros. ${ }^{12}$

Lo interesante de la biopolítica, para efectos de este trabajo, es que ésta no tiene tanto que ver con una política liberal de la vida biológica de los sujetos, sino más bien trata acerca de una política de la población. ${ }^{13}$ Por lo tanto, la biopolítica en cuanto dispositivo de control se encuentra anudada a una problemática mayor, que dice relación con la emergencia de aquello que se ha llamado "gestión de gobierno"; y ello comprende un conjunto de "técnicas de gobierno que sirven de base a la formación del Estado moderno". ${ }^{14}$ A grandes rasgos, estas técnicas de gobierno contribuyeron a la instauración de toda una racionalización respecto del "arte de gobernar" a la población como una masa cuantificable y moldeable. ${ }^{15}$

Nos parece necesario recalcar que el concepto de gubernamentalidad, en ningún caso implica una sucesión o una sustitución secuencial de una sociedad de soberanía por una sociedad disciplinaria y de ésta hacia una sociedad de gobierno o poblacional, sino más bien se trata de "un triángulo: soberanía, disciplina y gestión gubernamental, una gestión cuyo blanco principal es la población y cuyos mecanismos esenciales son los dispositivos de seguridad". ${ }^{16}$ De ahí que la noción de gubernamentalidad nos introduce en un domino más amplio de análisis, que nos permite entender el modo en que el neoliberalismo de la transición a la democracia utilizó a la población chilena como un objeto de intervención gubernamental, y más específicamente, nos ayuda a entender el modo en que la delincuencia y por extensión la pobreza, se configuran como experiencias que requieren ser controladas, manipuladas y clasificadas por los dispositivos de seguridad, los mecanismos disciplinarios y por la intervención biopolítica.

En términos metodológicos trabajaremos desde de la idea de que las películas pueden ser tratadas como texto y, por lo tanto, son susceptibles de ser deconstruidas a partir de la noción de lexias o unidades de lecturas propuesta por Roland Barthes. Las lexias son aquel "significante tutor [que puede ser] dividido en una serie de cortos fragmentos contiguos". ${ }^{17}$ Las lexias filmicas comprenderán a veces unas pocas escenas o secuencias, en otros momentos utilizaremos algunos planos, o bien recurriremos a determinados diálogos o parlamentos que nos ayuden a encontrar "el mejor espacio posible donde se puedan observar los sentidos, (...) [lo cual] dependerá de la densidad de las connotaciones que es variable según los momentos del texto". ${ }^{18}$ Nuestro material de análisis está constituido por aquellas cintas

\footnotetext{
12 Michel Foucault, Defender la sociedad. Buenos Aires: Fondo de Cultura Económica, 2000.

${ }^{13}$ Dodier Fassin, "Otra política de la vida es posible: crítica antropológica del biopoder", Vanessa Lemm (editora) Michel Foucault: neoliberalismo y biopolítica. Santiago de Chile: Ediciones Universidad Diego Portales, 2010, pp. 21-49. Si bien el concepto de biopolítica nos introduce en los diversos mecanismos de poder con los que se comienza a operar un arte de gobernar liberal y neoliberal; no es menos cierto que este concepto se configuró, en Foucault, como una noción temporal que "cumple la función de 'puente' entre el modelo bélico y el modelo gubernamental" Santiago Castro-Gómez, Historia de la gubernamentalidad I. Razón de Estado, liberalismo y neoliberalismo en Michel Foucault, Bogotá: Siglo del Hombre Editores, 2015, p. 65). Ahora bien, es posible apreciar cómo en los cursos del Colegio de Francia dictados por el filósofo francés a partir del año 1975 -Defender la Sociedad (2000), seguido de Seguridad, Territorio y población (2006); y finalmente Nacimiento de la biopolítica (20016)-, se intentan vincular el concepto de biopolítica con la soberanía (Defender la sociedad), con las problemáticas de la población (Seguridad, territorio y población) y con el problema del arte de gobernar liberal y neoliberal (Nacimiento de la biopolítica). Sin embargo, como señala Gilles Deleuze (1987), el pensamiento de Foucault se encuentra atravesado por entrecruzamientos y dimensiones hilvanadas bajo exploraciones creativas y conceptuales, que para el caso del biopoder "requiere una reubicación en un marco más grande de análisis: el examen histórico de las condiciones materiales de formación de la población como campo de intervención gubernamental" (CastroGómez, op. cit., p. 65).

14 Michel Senellart, "Situación del curso", Seguridad, territorio y población. Buenos Aires: Fondo de Cultura Económica, 2006, p. 448.

15 Foucault, op. cit. 2006.

16 Foucault, op. cit. 2006, p. 135.

17 Roland Barthes, S/Z, Buenos Aires: Siglo XXI Editores, 2001a, p. 9.

18 Barthes, op.cit., p. 9.
} 
producidas en Chile durante la transición a la democracia y que tienen como protagonistas al lumpenproletariado. ${ }^{19}$ Analizamos, siguiendo esta premisa, Caluga o menta (1990) de Gonzalo Justiniano, Johnny cien pesos (1993) de Gustavo Graef Marino; Taxi para tres (2001) de Orlando Lübbert y Mala leche (2004) de León Errazuriz.

Sostenemos que en el cine de la transición a la democracia la representación audiovisual del delincuente se encuentra atravesada e impregnada por una racionalidad y una gubernamentalidad neoliberal, que contribuye a la inscripción fílmica de la delincuencia como subjetividad ahistórica y, con ello, la imagen del delincuente se articula como singularidad que tiende a la atomización del mundo popular-marginal. De este modo, la delincuencia como problemática social queda enclaustrada, es decir, se la cosifica y se la oculta bajo representaciones que difunden la imagen de una marginalidad sobreexpuesta y que funciona bajo lo que Didi-Huberman llama "la paradoja de los figurantes: tienen un rostro, un cuerpo, gestos bien característicos, pero la puesta en escena que los demanda los quiere sin rostro, sin cuerpo, sin gestos característicos" ${ }^{20}$

\section{Transición, capitalismo de consumo y delincuencia}

En Chile, el neoliberalismo se impuso bajo el entramado dictatorial como una política económica que tenía como objetivo la modernización del país a través de la instalación del mercado como el eje estructural y estructurante de la sociedad chilena. Con la llegada de la democracia la economía de mercado dio paso a una sociedad de mercado, es decir, las relaciones sociales se originan a partir de la centralidad del mercado como agente regulador, donde "los valores mercantiles penetran en cada aspecto de las actividades humanas". ${ }^{21}$ De este modo, en los años noventa se pasa de una economía neoliberal autoritaria hacia una sociedad de mercado que funciona sobre la base de lo que Carlos Huneeus ha llamado una democracia semisoberana, y con ellos quiso caracterizar el conjunto de limitaciones institucionales y políticas que no permitieron crear espacios de participación y democratización, sino que se continuó limitando el poder de los ciudadanos. ${ }^{22}$ En consecuencia, la transición de la dictadura a la democracia implicó una coyuntura crítica, que redefinió algunos aspectos institucionales, continúo con algunas políticas, principalmente económicas, y produjo un realineamiento de las élites.

Lo que nos interesa describir aquí es el modo en que la Concertación internalizó y domesticó el neoliberalismo como ideología y como práctica gubernamental, que hizo del mercado y del consumo el ente rector que ordenó y gobernó buena parte de la mentalidad concertacionista. ${ }^{23}$ Nos interesa

${ }_{19}$ De acuerdo con Marx y Engels, el lumpenproletariado puede ser definido como aquella porción de la población que se encuentran debajo de la clase obrera y, por lo tanto, están al margen del proceso de producción, es decir, se encuentran socialmente marginados. De este modo, el lumpen-proletariado es una clase social vulnerable, que tiende al individualismo porque no posee un sentido de pertenencia social, por lo que fácilmente pueden manifestar conductas delictivas o antisociales, y se constituyen como una fracción dominada de la clase dominante. Karl Marx y Friedrich Engels, La ideología alemana. Barcelona: Ediciones Grijalbo, 1974.

20 Georges Didi-Huberman, Pueblos expuestos. Pueblos figurantes. Buenos Aires: Manantial, 2014, p. 156.

21 Michel Sandel, Lo que el dinero no puede comprar. Los límites morales del mercado, Buenos Aires: Debate, 2013, p. 18.

22 Carlos Huneeus, La democracia semisoberana. Chile después de Pinochet, Santiago de Chile: Taurus, 2014.

${ }^{23}$ La Concertación estuvo conformada por el Partido Demócrata Cristiano (PDC) y sus variantes conservadoras y progresistas, el Partido Radical Social Demócrata (PRSD), el Partido Socialista (PS) y el Partido por la Democracia (PPD) que surgió como una escisión del PS con la intención manifiesta de ser un partido instrumental para el plebiscito de 1988. La Concertación gobernó ininterrumpidamente entre los años 1990 y 2010, conquistando cuatro gobiernos, dos encabezados por democratacristianos: Patricio Aylwin (1990-1994) y Eduardo Frei Ruiz Tagle (1994-2000), y 2 encabezados por socialistas: Ricardo Lagos (2000-2006) y Michel Bachelet (2006-2010). Esta coalición política se estableció como una coalición híbrida de centroizquierda, que intentó introducir un neoliberalismo corregido basado en una política de equidad redistributiva, y un progresismo limitado basado en una política de los consensos (Manuel Castells, Globalización, desarrollo y democracia: Chile en el contexto mundial. Santiago de Chile: Fondo de Cultura Económica, 2006). A grandes rasgos, se trató de gobiernos que tuvieron que actuar bajo una política tutelada por el ejército y los poderes fácticos de la derecha pinochetista, que ajustó el ejercicio del 
particularmente analizar el consumo como posibilidad hedonista de participación y reconocimiento social, que engendró "una suerte de disociación entre la vida privada y la esfera pública. La primera satisfecha, la segunda no (...) Es lo que puede denominarse la paradoja de Chile. Los chilenos (y chilenas) están simultáneamente felices y molestos". ${ }^{24}$ Nos parece que la paradoja chilena encuentra en la figura del delincuente un correlato disruptivo, porque se trata de una subjetividad que se encuentra escindida del contrato social neoliberal en donde todos, supuestamente, nos enriquecemos juntos. De ahí que la delincuencia se configure como una problemática de gobierno que, desde los aparatos ideológicos del Estado, es pensada como fenómeno de seguridad, disciplinamiento, vigilancia y control del delito a través, por ejemplo, de los dispositivos jurídico-carcelarios, o de los dispositivos biopolíticos ligados a la instauración del miedo como mecanismo de control.

Antes de centrar nuestro análisis de la delincuencia como fenómeno disruptivo del neoliberalismo, nos parece necesario contextualizar la expansión del consumo y la sociedad de mercado que se impuso en el chile de la transición, porque estos elementos se constituyen como factores clave para la consolidación de la democracia de los acuerdos que, luego del violento y sangriento paisaje que impuso el quiebre dictatorial, requirió consolidar un proyecto de gobierno que no tuvo mayor alternativa que negociar con los poderes fácticos del autoritarismo pinochetista -fuerza armadas y empresariado-; quienes impusieron su derecho a veto como prerrequisito para aceptar la democracia política. ${ }^{25}$ En tal sentido, el ir generando una sociedad de mercado basada en el consumo se constituyó en una condición de posibilidad para la consolidación de la democracia semisoberana. De ahí que la búsqueda de un consenso político por parte de la Concertación estuvo basada en la continuidad de la legitimidad del mercado, al cual la política concertacionista añadió "un correctivo fundamental: el Estado dejó de ser instrumento de exclusión para ser instrumento de integración”. ${ }^{26}$

El censo del 2002 reveló un país modernizado por el consumo, ${ }^{27}$ dato detrás del cual se revela una alienación de las subjetividades vía fetichización del consumo como deseo que enclaustró a los sujetos en un movimiento bipolar de placer/frustración. ${ }^{28}$ Bajo este contexto las identidades se fragmentaron de acuerdo con las posibilidades objetivas (dinero y acceso al crédito) que el mercado y el sistema de redistribución ofrece a cada uno de los individuos, según las variables posiciones que cada uno ocupa dentro del sistema de clasificación y control financiero al que se ven expuesto los ciudadanos. ${ }^{29}$ Este proceso de fetichización del consumo produjo lo que Kathya Araujo y Danilo Martuccelli llaman la fiesta y la resaca, metáfora con la cual quieren designar el modo en que en Chile se transitó de un estado de euforia -en la década de los noventa-, a uno de desánimo -en la década de los dos mil. El primero se produce gracias al nuevo clima político democrático, junto con "los primeros verdaderos signos tangibles de un incremento significativo del poder adquisitivo y de una esperanza inusitada del futuro del país (el

poder a los principios del mercado, y funcionó “en base a las gramáticas de la moderación y la resignación que dilataron la imagen de una temporalidad uniforme y de plazo definido, sin rupturas de planos ni sobresaltos de secuencias" (Nelly Richard, Latencias y sobresaltos de la memoria inconclusa (Chile: 1990-2015). Buenos Aires: EDUVIM, 2017, p. 27).

${ }_{24}$ Carlos Peña, Lo que el dinero si puede comprar. Santiago de Chile: Taurus, 2017, p. 27.

25 Castells, op. cit.

26 Ibid., p. 119.

27 Eugenio Tironi, Cuánto y cómo cambiamos los chilenos. Balance de una década. Censos 1992-2002. Santiago de Chile: INE, 2003.

28 Tomás Moulian, El consumo me consume. Santiago de Chile: LOM Ediciones, 1998. Pierre Bourdieu, La distinción. Criterios y bases sociales del gusto. México: Taurus, 2002.

29 A este respecto, Tomás Moulian, sostiene que la consolidación y masificación del crédito financiero trajo consigo todo un entramado de clasificación, vigilancia y control de los clientes. La vigilancia se configura como resultante estructural de las economías neoliberales que funcionan a partir de la antinomia que promueve e incita al consumo, pero proveen trabajos precarios y mal remunerados, lo que trae aparejado el endeudamiento, el cual se constituye como un mecanismo de control (Moulian, op.cit.) 
Chile jaguar)" ${ }^{30} \mathrm{El}$ segundo es lo que deja el festejo pantagruélico del consumo y se manifiesta como síntoma de la alienación cultural, que se materializa como malestar social, sobreendeudamiento, pérdida de confianza en las instituciones y desafección por el interés común y la política.

La fetichización del consumo como deseo y el estado bipolar de placer/frustración, fiesta/resaca, contribuyó en la inscripción de una identidad "penetrada por la simbólica del consumo";31 que se encuentra atravesada por lo que en clave psicoanalítica se llama "lo abyecto", esto es, aquello que a la vez atrae y se resiste, aquello que encanta y repele. ${ }^{32}$ Uno de los resultados tangibles de todo esto es que la población "está molesta y al mismo tiempo feliz: parece haber disociado su vida personal (que la juzga más que satisfactoria) de su entorno social (al que, en cambio, juzga deplorable)". ${ }^{33}$ Esta disociación entre lo público y lo privado, entre el individuo y el colectivo, trae consigo el debilitamiento de la política, y ello implica no sólo la despolitización de la sociedad, sino también contribuye a que en el discurso público las clases sociales y el pueblo como categoría política desparezcan y, en su lugar "se implantan nuevas matrices de representación de lo popular". ${ }^{34}$

En consecuencia, el debilitamiento de la política como espacio de deliberación y negociación de los problemas que afectan el interés colectivo, sumado a la obsesión por la riqueza y la expansión del consumo como reconocimiento social, se constituyen como uno de los dispositivos de modelamiento de la población durante la transición. De ahí que se pueda inferir que la delincuencia es vista como una respuesta a la imposibilidad de acceso al consumo que experimentan las clases bajas. Como ha observado Tomás Moulian, la despolitización de la sociedad da paso a un estado de incertidumbre que tiene el efecto de producir un aumento de la delincuencia y de la violencia no política. Es decir, aquellas problemáticas sociales, como pueden ser la pobreza y la exclusión social, al no lograr ser resueltas por la vía política de la deliberación, de la negociación o por "la acción colectiva orientada a fines, busca en el delito desesperado o rabioso, el último recurso para salir de la marginalidad". 35

Desde los primeros años de la transición, la prensa y los partidos de derecha cumplieron un rol fundamental en instalar el tema del delito como una de las principales preocupaciones de la población. "La seguridad ciudadana y la comunicación tienen una relación muy fuerte y recíproca, esto, entre otras cosas, debido a la gran incidencia de los medios de comunicación de masas en la amplificación de hechos delictivos que, a lo menos, impactan negativamente en la percepción de los ciudadanos respecto al temor". ${ }^{36}$ Existen dos grandes hechos, ambos ocurridos en el año 1991 que ayudaron instalar el tema de la seguridad ciudadana como un problema político: uno fue el asesinato de senador de derecha Jaime Guzmán, el otro el secuestro de Cristián Edwards, hijo del dueño del diario El Mercurio. A partir de estos dos hechos, la coalición de derecha llevó a cabo una campaña comunicacional que tenía por finalidad deslegitimar las políticas de seguridad del gobierno e instaló la idea de que en Chile se vivía una inseguridad ligada a la violencia terrorista de grupos de izquierda y a la violencia de la delincuencia común. ${ }^{37}$

\footnotetext{
${ }^{30}$ Kathya Araujo y Danilo Martuccelli, Desafíos comunes. Retrato de la sociedad chilena y sus individuos, Tomo 1. Santiago de Chile: LOM Ediciones, 2012, p. 64.

31 Tomás Moulian, Chile: anatomía de un mito, Santiago de Chile, LOM Ediciones, 1997, p. 106.

32 Peña, op. cit.

33 Ibid., p. 27-28.

34 Moulian, op. cit. 1998, p. 46.

35 Ibid., p. 47.

36 René Jofré, "Seguridad Ciudadana y estrategias de Comunicación en Chile", Elisabet Gerber (ed.) Politicas de Seguridad Ciudadana. La agenda ausente en el Cono sur. Santiago de Chile: Centro de Competencia en Comunicación para América Latina y Friedrich Ebert Stiftung, 2006, p. 77.

37 Juan Pablo Acevedo Moya, "Crimen y castigo en el Chile democrático: la derecha y la seguridad ciudadana en los noventa. 1990-1994”, Revista Divergencia Nº 7, 2016, pp. 65-78.
} 
En términos comunicacionales el tratamiento de la delincuencia y del control del delito fue afrontado como una problemática de orden social focalizado en la figura del delincuente y del delito como amenaza para el conjunto de la población. El transgresor es un enemigo que requiere ser controlado, vigilado y castigado por la institucionalidad jurídico/estatal/policial; puesto que su accionar implica no sólo una desviación del contrato social, sino una completa enajenación respecto de las normas y valores que guían la vida social dentro de la hegemonía neoliberal. De ahí que el delincuente -en su constitución social (objetiva) y simbólica (imaginaria y representacional)- se constituye como subjetividad en los márgenes, a la cual "la sociedad le teme como a todo aquello que no ha podido someter, y por ende desconoce y tiende a cargar de contenidos simbólicos". ${ }^{38}$

Los dispositivos biopolíticos reducen la delincuencia a una cuestión de modelamiento de las emociones a partir del miedo a los subordinados; los mecanismos disciplinarios ven en la prisión un espacio de modelamiento de la conducta, y los dispositivos de seguridad establecen una serie de instrumentos estadísticos que permiten caracterizar a la población a través de cálculos de riesgo, que establecen zonas geográficas de mayor o menor probabilidad de delitos. Por lo tanto, la problemática de la delincuencia no es pensada como un problema social derivado, por ejemplo, de la ausencia de un estado de bienestar que pudiera contribuir en la reducción de los delitos, sino que es gestionada a partir de la relación entre Estado y mercado, de modo que de ahora en más, la pobreza en general y la delincuencia en particular se constituyen, en el Chile de la transición, en "una excrecencia irreductible a la historia que lo precede porque introduce una antinomia cuya figura y efectos eran desconocidos hasta entonces". 39

A la estrategia de dominación y control del delito sustentado sobre una base represiva, vigilante y castigadora, habría que sumar la instauración del miedo como dispositivo de control. El miedo a la delincuencia es canalizado por la relación estructural entre Estado y Mercado, en donde el Estado neoliberal concertacionista "estimulará a la ciudadanía para que sea activa en asumir conductas de prevención del delito (...) Se plantea así, junto con la acción de los instrumentos estatales, una co-gestión privatizada de la seguridad". ${ }^{40}$ Esta co-gestión público privada se traduce, por ejemplo, en la construcción de diez cárceles que a En consecuencia, la gestión gubernamental de la delincuencia en Chile será una cuestión público-privada, que como ha observado David Garland, ha producido una mutación en los dispositivos de control del delito que "han sido moldeados por dos fuerzas sociales subyacentes, concretamente la organización social distintiva de la modernidad tardía y las políticas de libre mercado". ${ }^{41}$ Este moldeamiento se traduce, por ejemplo, en la política pública desarrollada por el gobierno de Ricardo Lagos que impulsó la concesión de diez nuevas cárceles que por primera vez contaron con la inversión de capitales privados, cuyos empresarios no solo asumen la tarea de construir los edificios, sino también de administrar los recintos haciéndose cargo de la alimentación de los reclusos y de otros servicios que se desprenden del sistema carcelario. ${ }^{42}$

En consecuencia, podemos argumentar que desde una perspectiva discursiva la problemática de la seguridad ciudadana y la gestión gubernamental del delito en el Chile de la transición se configuran como un entramado doctrinario que polariza el entorno social a través del binarismo amigo/enemigo, donde los delincuentes son clasificados como adversarios hostiles a la sociedad a los que hay que reducir, controlar o expulsar. ${ }^{43}$ Esta concepción discursiva de la seguridad ciudadana se configura como un

\footnotetext{
38 José Joaquín, Brunner, Apuntes sobre la figura cultural del pobre. Documento de trabajo Nº 69/78. Santiago de Chile: FLACSO, 1978, p. 27.

39 Roberto Esposito, Bíos. Biopolítica y filosofía. Buenos Aires: Amorrortu Ediciones, 2011, p. 175.

40 Iván Pincheira, "El Gobierno del miedo", Luna Follegati y Rodrigo Karmy (comp.) Estudios en Gubernamentalidad. Ensayos sobre poder, vida y neoliberalismo. Viña del Mar: Asociación Comunes, 2018, p. 268.

${ }^{41}$ David Garland, La cultura del control. Crimen y orden social en la sociedad contemporánea. Barcelona: Gedisa, 2012, p. 14.

42 Doris Cooper, Delincuencia y desviación juvenil, Santiago de Chile: LOM Ediciones, 2005.

43 Marcela Ramos y Juan Andrés Guzmán, La guerra y la paz ciudadana, Santiago de Chile: LOM Ediciones, 2000.
} 
modelo de sociedad que permite entender y dar respuesta a la gran mayoría de los problemas sociales ligados con la delincuencia común, ya que es el miedo al otro el que se instituye en uno de los elementos centrales que conforman las interacciones sociales, de modo que la seguridad ciudadana, en tanto discurso hegemónico de control social sería visto como un problema político y no social. ${ }^{44}$

En suma, durante la transición hubo una gestión de gobierno que hizo de la expansión del mercado el eje mediante el cual la democracia logró sobrevivir durante la postdictadura. Se trató de una estrategia política que trajo aparejada una cultura y una sociedad de mercado que no sólo implicó que el dinero se transformara en un objeto de pasión que no sólo "adquiere un posicionamiento simbólico (...), [sino] que el dinero [y el consumo] se hace poder, identidad, felicidad". ${ }^{45}$ Esto trajo consigo una serie de implicancias políticas tales como la degradación de la democracia que muta hacia una plutocracia (el gobierno de los ricos y para los ricos), se allanó el camino para que las corporaciones transnacionales colonizaran las instituciones políticas, y así favorecer los procesos de privatización de la educación, la salud, las pensiones o la cultura, los que son reducidos a una cuestión económica. ${ }^{46}$ Por otra parte, esta racionalidad ha propiciado que la distribución de la riqueza en Chile sea una de las más desiguales del planeta, y esto se traduce en que la pobreza y la exclusión social se encuentren sumergidas dentro de un espiral de reproducción social de la miseria y la precariedad.

\section{Cine y delincuencia}

Cada película constituye por sí misma una realidad fílmica y, por lo tanto, elabora sus propias condiciones de inteligibilidad y estrategias de verosimilitud. Ello implica que cada cinta pueda ser valorada en virtud de las estéticas, los discursos y las significaciones que pone en pantalla, y por lo tanto, lleva inscrita "lo que podría denominarse su lugar en la distribución global del poder cultural" ${ }^{47}$ Sin embargo, también sabemos que toda película comparte procedimientos de significación más o menos estandarizados, que se encuentran, hasta cierto punto, predeterminados por una cuestión tecnológica (la cámara, el sonido), por las convenciones narrativas propias del cine (encuadres, montaje, ritmo, etc.), pero también por ciertas características específicas del signo fílmico, y que Roland Barthes caracteriza como una "relación esencialmente analógica, no arbitraria" entre los significantes y los significados. ${ }^{48}$

\footnotetext{
${ }_{44}$ Desde la perspectiva de la Teoría del Continuo Subcultural de la Delincuencia, la socióloga Doris Cooper, se propone cuestionar los enfoque totalizantes de algunos paradigmas criminológicos que ha sustentado la idea de una delincuencia indiferenciada, proponiendo en cambio la hipótesis de la "existencia de una Tipología de la delincuencia fundamentada en Delincuencia Subculturales [donde es posible distinguir] cuatro tipos de delincuencia asociados a subculturas diferenciales" (Doris Cooper, "Teoría del continuo subcultural de la delincuencia" Revista de Sociología No 4, 1989, p. 118). La socióloga chilena plantea que la problemática de la delincuencia común se etiologiza a partir de conflictos socioculturales específicos y diferenciales que responden a variables de base tales como la pertenencia ecológica, sexual o etnia dentro de las clases bajas chilenas (Doris Cooper, "Delincuencia urbana femenina en Chile: una delincuencia que se moderniza", Revista de Derecho, Criminología y Ciencias penales, $N^{\circ} 1,1999$, pp. 179, 184). Los conflictos etiologizantes, nos dice Cooper, conllevan diferenciaciones que dependen del grado de desarrollo urbano-industrial económico y cultural en oposición al grado de ruralidad y tradicionalismo económico y subcultural de cada una de las áreas ecológicas consideradas, por lo tanto, "los grados de desarrollo versus subdesarrollo permiten predecir los tipos de delincuencia predominantes en un área ecológica” (Idid, p. 180). En consecuencia, la problemática de la delincuencia común y la desviación social en Chile se constituyen como un fenómeno complejo que responde a una serie de problemáticas sociales, culturales, políticas y económicas que están interrelacionadas que conforman o contribuyen a conformar una contracultura del hampa. Esta contracultura ha sido analizada por Doris Cooper a través de tres grandes líneas. La primera hace referencia a las características socioeconómicas de los delincuentes, la segunda dice relación con el sistema carcelario caracterizado como un espacio de hacinamiento, mientras que la tercera esfera se refiere a la problemática sexual de los reos al interior de las cárceles chilenas (Doris Cooper, Delincuencia común en Chile, Santiago de Chile: LOM Ediciones, 1994).

45 Moulian, op. cit., 1998, pp. 32-33.

46 Wendy Brown, El pueblo sin atributos. La secreta revolución del neoliberalismo, Barcelona: Malpaso Ediciones, 2017.

${ }^{47}$ Fredric Jameson, La estética geopolítica: cine y espacio en el sistema mundial, Barcelona: Paidós, 1995, p. 18.

48 Roland Barthes, "El problema de la significación en el cine", Roland Barthes La torre Eiffel. Textos sobre la imagen. Barcelona: Paidós, 2001b, p. 34.
} 
En tal sentido, nos parece que los modos de significación cinematográficos se transforman no sólo de acuerdo a determinados contextos fílmicos de producción, postproducción y exhibición de películas que logran influenciar el campo cinematográfico a través de relatos, narrativas y estéticas que pueden ser dominantes, emergentes o residuales, sino que los modos de significación también cambian en virtud de una cohabitación con los contextos extrafílmicos en los que las películas se encuentran inmersos. En consecuencia, el análisis de cada película permite relacionar una determinada formación social con las significaciones filmicas inscritas en ella. Examinar esta doble dimensión implica comprender las películas como unidades particulares y significativas de enunciación simbólica, al mismo tiempo que una mirada general acerca de aquellos elementos comunes arrojan luz sobre un tiempo histórico. Es en base a esa historicidad, que a continuación examinamos cómo se positiva en la figura audiovisual del delincuente (y en la delincuencia), la gubernamentalidad y los modos de subjetivación neoliberal que hemos descrito más arriba.

La película Caluga o menta. (1990) de Gonzalo Justiniano se inicia con un cartel que dice: "A fines de los años ochenta uno de cada tres jóvenes chilenos entraba en la categoría de lo que comúnmente llamamos marginales". ${ }^{49}$ Luego de los créditos de presentación, un plano general nos presenta un sitio eriazo, unas torres de alta tensión y una autopista. La cámara hace un paneo a la izquierda y desde una perspectiva cenital comienza a descender hacia donde hay cuatro jóvenes que están tomando el sol en medio de un descampado polvoriento: uno tendido sobre en una rueda de camión, otro tirado sobre cartones, más allá uno sentado en una silla de playa maltrecha, y cerca de éste un cuarto personaje tirado en un sofá. Uno aspira pegamento, otro juega desganadamente a apuntarle con piedras a un vaso de agua que está en el capó de un oxidado automóvil. Hace calor. El espacio se dibuja seco y sofocante. Es un espacio urbano desértico, donde estos jóvenes marginalizados pasan la tarde, pasan los días. Así lo confirma una voz en off:

Recuerdo que ese día que caí en el planeta. Estaba sólo a dos megamicas del objetivo. Solo, desamparado, sin destino, decidí seguir adelante con mi misión. En mi primer contacto con los nativos aprendí que el tiempo en este planeta se dividía en días, lo que nunca logré entender, pues todos los días eran iguales. Ellos estaban siempre ahí, como abandonados. ${ }^{50}$

Esta escena es una representación de la decadencia de la juventud poblacional de inicios de la postdictadura, no sólo porque en ella se retrata de un modo realista la marginalidad social que experimentan los jóvenes que habitan la periferia de las grandes ciudades, que después del autoritarismo pinochetista dejó al país con más de cuatro millones de pobres, es decir, más de un tercio de la población viviendo en la indigencia; ${ }^{51}$ sino también porque esa escena tiene un poder de propagación metonímica que nos hace pensar en las condiciones sociales de aquellos jóvenes desechados por la sociedad neoliberal y situarnos, ya no en la dictadura, sino en sus nefastas consecuencias sociales. Esta cinta será paradigmática del cine del período de la transición, porque es la primera que vincula pobreza con marginalidad, delincuencia y juventud, e introduce en el imaginario fílmico ciertas claves narrativas que serán características del llamado cine de la marginalidad latinoamericana, un cine que pone el acento sobre problemáticas sociales ligadas a los niños de la calle, la drogadicción, la violencia, la criminalidad, la indolencia, entre otros.

La representación de la marginalidad en Calugua o menta se inscribe como una problemática que se encuentra escindida del resto de la sociedad, incluso se encuentra separada de su propia clase social. De

49 Extracto tomado de la cinta Caluga o menta.

50 Extracto tomado de la cinta Caluga o menta.

${ }^{51}$ Huneeus, op. cit. 
este modo, la cinta de Justiniano esboza un lumpenproletariado que se halla en los contornos del mundo, que no participa del todo en él, pero tampoco está totalmente separado. Así lo atestigua la escena en el que el protagonista -el Niki- bebe cervezas en un bar de mala muerte con sus amigos -el Nacho, el Rorro y el Toño. La cámara los toma en un plano medio y sus rostros denotan angustia, tensión, dureza y encierro. Uno de ellos dice: "Cuando estaba preso tenía una esperanza: salir pa' fuera, encontrar algo distinto. Libertá." 52 Con ello se quiere significar el desencanto de un sujeto que habita la periferia de la ciudad en donde los beneficios de la modernización neoliberal no han llegado todavía. El estado anímico del personaje se refuerza cuando dice: "Desde que nacimos estamos sobrando". ${ }^{53}$ La escena se cierra con el Nacho expresando de manera irónica: "Somos privilegiados, no tenemos nada que perder". ${ }^{4}$

Esta escena visibiliza la autopercepción de los protagonistas respecto de su propia inmovilidad social y que se traduce en un desinterés respecto de su presente. Se trata de jóvenes abandonados por sus familias, por el Estado y por las instituciones y, con ello, la cinta fabrica la imagen de una subjetividad marginal sumida en una condición de perpetua exclusión. Este estado de supresión de futuro produce una relación socialmente anómala entre sujeto y sociedad. ${ }^{5}$ Por ejemplo, la forma en que los marginales se relacionan con la clase acomodada está reducida a tres vías de vinculación: delincuencial, servicial y sexual. Los marginales roban las casas de aquellos que están en mejor situación económica; hacen algunos servicios, ligados principalmente al transporte y venta de drogas y, por último, ofrecen servicios sexuales ya sea a través de la prostitución homosexual o como encuentros fortuitos.

En Caluga o menta el discurso denotado muestra la marginalidad delincuencial como abandono y vagancia, como perversión e inmoralidad; en términos de su connotación subyace la idea de que la marginalidad conlleva un estado de desafección y escepticismo de lo político. En la película de Justiniano esto se traduce en desconfianza y desinterés hacia el nuevo orden político-democrático y hacia las instituciones gubernamentales que lo conforman, puesto que ellas no han conseguido modificar la situación de pobreza, exclusión social y abandono en el que se encuentran. Así lo atestigua la secuencia donde un funcionario municipal les informa a los jóvenes que pronto harán algunas mejoras en el sector:

Feto: ¡Hey! ¡Van a poner pasto, van a poner pasto!

Niki: Antes venían a ponernos palos y ahora vienen a ponernos pasto, ¿cómo está?

Rorro: La democracia, pus loco, llegó la democracia.

Funcionario: Buenas tardes. Y ustedes, jóvenes, ¿̇en qué andan?

Nacho: Nosotros, aquí, esperando que nos pongan pasto

Funcionario: Nos interesa saber la opinión de ustedes los jóvenes, porque... vamos a poner áreas verdes en este sector y juegos, en fin...

Rorro: Sí, bonito. Se imaginan, loco, todo verde.

Niki: Aquí lo único que hay es pa' aburrirse.

Toño: A veces intentamos divertirnos ridículamente. Nos tomamos unas cervezas, unas pepas.

Rorro: Casi siempre terminamos muy mal. ¿Cierto? ¿Se le ofrece alguna otra pregunta?

Funcionario: Oye, viejo, yo también soy joven, también he fumado marihuana. Todos tenemos problemas, pero es asunto de todos tratar de solucionarlo.

Nacho: Nos han tenido todo el tiempo abandonados aquí y ahora... ¿ ‘ah?

Funcionario: La municipalidad tiene la mejor disposición. Lo único que quiero que sepan es que allá ustedes cuentan con un amigo. Bien, buenas tardes.

Toño: Tuvieron tanto tiempo y ahora recién se acuerdan de los locos, ahora que nos volvimos locos. ${ }^{56}$

\footnotetext{
52 Extracto tomado de la cinta Caluga o menta.

${ }^{53}$ Extracto tomado de la cinta Caluga o menta.

${ }_{54}$ Extracto tomado de la cinta Caluga o menta.

55 Ascanio Cavallo, et. al., Huérfanos y perdidos. El cine chileno de la transición. Santiago de Chile: Grijalbo., 1999.

${ }^{56}$ Extracto tomado de la cinta Caluga o menta.
} 
$\mathrm{Al}$ evidenciar la completa apatía respecto de los cambios que podría suponer el nuevo orden político para estos jóvenes marginalizados, la cinta no sólo critica el abismo entre las políticas gubernamentales tendientes a maquillar una determinada realidad social y los problemas acuciantes que aquejan a ese segmento de la población, sino también muestra una mirada paternalista y trivializada que definiría las políticas públicas sobre los entornos sociales menos favorecidos por la modernización neoliberal. La despolitización de la sociedad se constituye como una de las herencias directas del autoritarismo pinochetista que expuso, sistemáticamente, una propaganda de desprestigio a la política y a los políticos como una cuestión de "politiquería y demagogia". Esta secuencia en particular -en la que se condensa la apatía, la banalización, el paternalismo- presenta un escenario que desvalora la política y, con ello, se propicia la despolitización no sólo de los sujetos populares, sino también de la propia política. No es nuestra intención evaluar la exactitud de la representación o de los juicios subyacentes, sino evidenciar un imaginario que, al mismo tiempo que denuncia, fortalece una visión de la contingencia. Por otra parte, la misma cinta de Justiniano no consigue sobreponerse a esa despolitización, disfrazando y trivializando la problemática de la pobreza y la exclusión social. La película elabora un relato sustentado sobre lo que Roland Barthes ha denominado discurso encrático, ${ }^{57}$ es decir la película reproduce y distribuye la opinión común (la doxa) que se tiene respecto de la vida de los jóvenes que habitan la periferia de Santiago y, por lo tanto, se trata de una representación vaga y difusa que no logra tensionar, interpelar y desnaturalizar aquellas visiones culturalmente arraigadas sobre marginalidad social que asocian al pobre con la delincuencia, la vagancia, la violencia y el abandono.

En suma, Calugua o menta construye un relato acerca de los delincuentes (y de la delincuencia), que se configura como espectáculo -en el sentido que Guy Debord le da a este término. ${ }^{58}$ Esto porque la representación que se fabrica del delincuente y su entorno social, no consigue tensionar la relación entre gobierno y pobreza, entre política y ciudadanía, y, por lo tanto, no logra anclar un discurso acrático, es decir, una representación basada en un pensamiento político que resignifique la doxa o el sentido común acerca de la pobreza y la marginalidad. ${ }^{59} \mathrm{Si}$ bien la película de Justiniano condensa las inequidades sociales como continuidades residuales del autoritarismo pinochetista, el cual ocultó a fuerza de represión y propaganda la pauperización de las clases populares; la cinta también refuerza una de las transformaciones culturales que hizo la dictadura respecto de los sectores populares, desvinculando a los barrios periféricos de conceptos como dignidad y resistencia política, para convertirlos en espacios sociales en los que habita el delito, las drogas, la decadencia moral. Es a ese imaginario neoliberal, ampliamente divulgado por los medios de comunicación de masas, al que recurre Caluga o menta para conformar un relato acerca del abandono, la desidia y la desesperanza que criminaliza la pobreza y la vuelve una cuestión factual y no procesal. La película no pretende ser crítica acerca de las transformaciones e inequidades que el neoliberalismo autoritario produjo sobre los sectores populares, sino presentar un momento y un espacio aislado en el que "los amigos del Niki se sienten no sólo marginados, sino literalmente fuera de la nación". 60

La cinta Caluga o menta utiliza la delincuencia juvenil para retratar el mundo sin futuro de los jóvenes que habitan los barrios periféricos de Santiago; por su parte, la película Johnny cien pesos (1993) de Gustavo Graef-Marino, utiliza un delito común -el asalto a un video club que funciona como pantalla de una casa de cambio clandestina- para narrar cómo un hecho delictual se transforma, primero, en un hecho noticioso ampliamente difundido por la televisión y luego, a partir de esa exposición mediática, se

\footnotetext{
${ }_{57}$ Roland Barthes, "La Guerra de los lenguajes”, Roland Barthes El susurro del lenguaje. más alla de la palabra y la escritura. Barcelona, Paidós, pp. 135-139.

58 Guy Debord, La sociedad del espectáculo, Valencia: Pre-Textos, 2007.

${ }^{59}$ Barthes, op. cit., 1987.

${ }^{60}$ Carvallo, op. cit. p. 102.
} 
conforma en un dilema político. En tal sentido, la cinta de Graef-Marino muestra tres problemáticas: la delincuencia común ligada a la pobreza, la exposición mediática y su capacidad de transformar la agenda política y, por último, la fragilidad de la transición a la democracia.

Basada en un hecho policial verídico ocurrido en el Santiago del año noventa, la película recoge estos tres factores y construye una historia que busca traspasar el particularismo del hecho real para intentar retratar el poder de la prensa como espacio de construcción de la realidad. El sensacionalismo mediático, que transforma un hecho delictual en un problema de seguridad nacional, se traduce en un conflicto entre el poder ejecutivo y el poder judicial-policial, en el contexto de una transición a la democracia tutelada por las fuerzas armadas. Al visibilizar dentro del texto fílmico el poder político-gubernamental, el jurídicopolicial y mediático-inquisidor, la cinta de Graef-Marino introduce el problema de la gubernamentalidad como una "topología que ve la política y el derecho, el poder y la ley, la decisión y la norma, situados en los polos opuestos de una dialéctica cuyo objetivo es la relación entre súbitos y soberanos". ${ }^{61}$ Esta oposición contribuye a describir superficialmente el peso relativo que cada uno de estos poderes tiene dentro de la transición a la democracia, puesto que el cambio de régimen constituyó "una coyuntura crítica durante la cual se redefinen instituciones y políticas". ${ }^{62}$

Lo que nos parece relevante de analizar es el modo en que la delincuencia es abordada por cada uno de estos poderes. Siguiendo a Michel Foucault, podemos distinguir tres grandes conjuntos mediante los cuales la cinta de Graef-Marino representa esta relación: los dispositivos jurídicos, los disciplinarios, y los securitarios, cada uno de los cuales posee formas específicas de tratar el delito. ${ }^{63}$ Así, por ejemplo, la forma en que el asalto al video club es abordado por el poder judicial opera bajo la fórmula de tipificación del delito y con ello lo ubica dentro de una clasificación que vincula crimen y castigo. "Se trata, pues, de un conjunto tecnológico que opera con el código binario prohibición/permisión". ${ }^{64}$ En cambio, los mecanismos disciplinarios, representados en la cinta por la intervención policial, conforman la cara visible de toda una red de control del delito, a través de la vigilancia, la represión y el encarcelamiento. El poder político, representado por los altos funcionarios de gobierno, no persigue sancionar las leyes, ni disciplinar a los delincuentes, lo que buscan es gestionar un hecho delictual para que no devenga en crisis política. Esta gestión se da a través de cálculos y mediciones que sitúan el fenómeno del crimen "dentro de una serie de acontecimientos probables", ${ }^{65}$ que permiten tomar decisiones con el menor costo político posible. Así lo atestigua la escena en que los funcionarios del gobierno debaten acerca de si deben o no autorizar la intervención policial: "El comandante ofrece un 80 por ciento de éxito en la operación"; 66 dice uno de los funcionarios. El cálculo de riesgo muestra la necesidad de gestionar gubernamentalmente la respuesta a la criminalidad "dentro de un intervalo aceptable, que no suponga una amenaza para la estabilidad del gobierno ni para el conjunto de la población". ${ }^{67}$

Al relevar la problemática de un incidente delincuencial común como una cuestión socio-mediática que incide directamente en el entramado político-jurídico-policial, la cinta de Graef-Marino realiza una inscripción tendiente a visibilizar la precariedad de la política chilena durante la transición y su condición de democracia vigilada. Esto se hace evidente no sólo cuando se representa el choque de fuerzas entre gobierno y poder judicial, sino también cuando los delincuentes -al verse rodeados por la policía- deciden que la mejor manera para negociar una salida es la de simular ser un grupo terrorista. "Mira Washington, hay que dárselas de terroristas para que te pasen un avión, ¿tú creí que a cualquier ladrón le pasan un

\footnotetext{
${ }^{61}$ Esposito, op. cit. p. 43.

${ }^{62}$ Huneeus, op. cit. p. 67.

${ }^{63}$ Foucault, op. cit., 2006.

64 Castro-Gómez, op. cit. p. 69.

${ }^{65}$ Foucault, op. cit., 2006, p. 21.

${ }^{66}$ Extracto de la película Johnny cien pesos.

${ }^{67}$ Castro-Gómez, op. cit. p. 70.
} 
avión y para ese viaje?”. ${ }^{68}$ Esta simulación es indicadora de que, a pesar de la ingenuidad política de los asaltantes, dentro del imaginario social de la postdictadura se entendía que la democracia vigilada debía entregar ciertas garantías a las fuerzas armadas, tales como evitar la emergencia de grupos marxistas, los cuales se constituían como la principal amenaza para el sistema político de la democracia protegida por el pinochetismo. ${ }^{69}$

La película Taxi para Tres (2001) de Orlando Lübbert aborda las consecuencias sociales que ha tenido la estructuración de una sociedad de mercado para una clase media baja empobrecida material y moralmente. Si bien el tema de la delincuencia y la marginalidad atraviesa todo el relato, la película de Lübbert evidencia el proceso de endeudamiento al que se ve sometida la clase media baja. Esto queda graficado a partir de la transformación que experimenta Ulises, un taxista que primero es secuestrado por dos asaltantes -El Chavelo y el Coto-, luego se transforma en el líder de la banda y finalmente se vuelve el verdugo de los asaltantes tras acordar un último asalto.

Una de las motivaciones iniciales de Ulises para involucrarse en los robos es terminar de pagar el crédito de su taxi. Sin embargo, resuelta esta necesidad, comienzan a surgir otros deseos de consumo: comprarse un televisor nuevo, pintar la casa, salir a comer con la amante, etc. Este deseo de consumo que manifiesta Ulises puede ser leído a la luz del concepto de "máquinas deseantes" propuesto por Deleuze y Guattari.70 La cinta de Lübbert esbozaría la perversión de la economía política neoliberal, la cual requiere para su funcionamiento la circulación constante del consumo como deseo. Dicho de otra manera, Taxi para tres expresa la instalación de una subjetividad neoliberal que apela a una suerte de pulsión libidinal que supone la organización social del deseo. En tal sentido, la película logra escenificar esta perversión que propicia un estilo de vida anudado al consumo, al flujo constante del deseo como "el elemento que va a impulsar la acción de todos los individuos". ${ }^{71}$ Por ejemplo, Ulises transita por varios estados deseantes, primero vemos emerger en él el deseo de salir de una deuda que lo tiene con el agua hasta el cuello, luego vemos surgir una pulsión por obtener dinero fácil para satisfacer el deseo de consumo y, finalmente, aparece el deseo de poder y dominación. Los asaltantes, en cambio, transitan un camino inverso al del taxista: ellos asaltan por la necesidad de resolver su subsistencia, pero también por el vértigo y el poder que conlleva el delito, para finalmente descubrir su deseo de redención que satisfacen a través de la iglesia evangélica y la propia familia del taxista.

A partir de los estados deseantes por los que transitan los protagonistas de Taxi para tres y siguiendo a Michel Foucault, podemos pensar en términos teóricos, acerca del modo en que el deseo requiere ser gobernado por los dispositivos de seguridad que se desprenden de la gubernamentalidad neoliberal. ${ }^{72}$ Ya no se trata sólo de disciplinar ni de reprimir el deseo, sino de organizar y gestionar su circulación. Esto porque el deseo se constituye no sólo en un elemento funcional a la economía neoliberal y su necesidad de expandir el consumo, sino que la producción social de la realidad se encuentra estructurada a partir de la producción deseante. ${ }^{73} \mathrm{La}$ dimensión productiva del deseo se establece, entonces, como marco de posibilidad para la consolidación de la sociedad neoliberal. Al respecto, Michel Foucault sostiene:

El deseo (...) reaparece ahora en las técnicas de poder y gobierno (...) El deseo es la búsqueda del interés para el individuo. Por otra parte, aunque éste pueda perfectamente ser engañado por su deseo en lo concerniente al interés personal, hay algo que no engaña: el juego espontáneo o, en todo caso, a la vez espontáneo y regulado del deseo permitirá, en efecto, la producción de un

\footnotetext{
${ }^{68}$ Extracto de la película Johnny cien pesos.

${ }^{69}$ Huneeus, op. cit.

${ }^{70}$ Gilles Deleuze y Félix Guattari, El Anti Edipo. Capitalismo y esquizofrenia. Barcelona: Paidós, 1998.

${ }^{71}$ Foucault, op. cit., 2006, p. 96.

${ }^{72}$ Foucault, op. cit., 2006

${ }^{73}$ Deleuze y Guattari, op. cit.; Castro-Gómez, op. cit.
} 
interés, algo que es interesante para la propia población. Producción del interés colectivo por el juego del deseo: esto marca al mismo tiempo la naturalidad de la población y la artificialidad posible de los medios que se instrumentarán para manejarla. ${ }^{74}$

La gubernamentalidad neoliberal supone el flujo de los deseos. Se trata de una producción y una productividad en constante expansión y por ello requiere de una gestión gubernamental que organice su libre movimiento, que propicie la eclosión de máquinas productoras o deseantes que no dejan de intervenir nunca en el flujo de la historia..$^{75}$ En consecuencia, no hay neoliberalismo sin un gobierno de los deseos, porque la economía política neoliberal requiere ir conformando nuevas necesidades, nuevas fantasías de consumo masivo; necesita crecer constantemente, precisa engordar para no perecer. La gestión gubernamental del deseo significa establecer "una esfera de actuación donde los individuos puedan escenificar y perseguir sus propios intereses". ${ }^{76}$ Se trata de prácticas de gobiernos tendientes a legitimar e institucionalizar estilos de vida y valoraciones simbólicas que contribuyen a gobernar los deseos de los individuos, pero dejando cierto margen para la iniciativa individual.

La gestión gubernamental del deseo nos introduce en otra problemática que tiene directa relación con los modos de subjetivación neoliberal asociados a la figura audiovisual del delincuente. Pablo Corro plantea que los pillos, los ladrones, los oportunistas y los delincuentes comunes que pueblan el cine chileno de los años noventa y principios del dos mil, funcionan retóricamente como "un fragmento o detalle ruinoso de la institucionalidad policial y de mercado dominante que tiene como trasfondo ético una doctrina del rendimiento". ${ }^{77}$ Se trata de una subjetivación de lo popular que naturaliza patrones de comportamiento y estilos de vida que responden a la norma dominante. En Taxi para tres esta construcción de la subjetividad popular muestra diversas facetas de los sujetos populares. Por ejemplo, los asaltantes pueden ser violentos, pero también son bromistas, amistosos, tienen un sentido del honor, experimentan afecto por la familia del taxista, -de hecho, el más joven, El Coto, se enamora de la hija de Ulises-, y transitan desde una amoralidad criminal hacia una moralidad evangélica. Al atribuirle matices a la figura del delincuente y su entorno social, la cinta de Lübbert consigue mostrar diversos aspectos de la vida social marginal, es decir, rompe con los estereotipos que caracterizaron al cine de la transición en su representación de la delincuencia limitándose a reproducir los esquemas de representación dominantes, los cuales "se conforma según el lenguaje imperante, o más bien, según aquello que el lenguaje parece imperar". 78

En contraste, la película Mala leche (2004) de León Errázuriz construye personajes unidireccionales, unívocos y estereotipados. En esta cinta se construye una representación sinonímica del mundo popular, es decir, se representa la marginalidad a partir de un conjunto restringido de significantes asociados a la marginalidad social (modos de hablar, maneras de vestir, formas de divertirse) que remiten a un único significado: la marginalidad y la pobreza engendran jóvenes perezosos, violentos y criminales.

La película de Errázuriz es un intento por retratar la figura del flaite, ese sujeto de clase baja que muestra comportamientos extravagantes y que se relaciona, por lo general, con el mundo delictual. ${ }^{79}$ Sin embargo, esta construcción es una imagen degradada de la subjetividad marginal que le asigna a la figura del joven marginal unas pocas características sencillas, que son fácilmente reconocibles y entendibles, y que por consiguiente reduce, esencializa, naturaliza y fija la diferencia bajo una mirada que clasifica al excluido

\footnotetext{
${ }^{74}$ Foucault, op. cit., 2006, p. 96.

75 Deleuze y Guattari, op. cit.

76 Castro-Gómez, op. cit., p. 85.

77 Pablo Corro, Retóricas del cine chileno. Ensayos con realismo. Santiago de Chile: Editorial Cuarto Propiop. 2012, p. 206

78 Roland Barthes, "Escritores, intelectuales, profesores", Roland Barthes Lo obvio y lo obtuso. Imágenes, gestos, voces, Barcelona: Paidós, 1986. pp. 321-322.

${ }^{79}$ Darío Rojas, "Flaite: algunos apuntes etimológicos", Alpha. Revista de artes, letras y filosofía N 40, 2015.
} 
como "otro", construyendo una frontera simbólica entre lo "normal" y lo "patológico", lo "aceptable" y lo "inaceptable", entre el "nosotros y el "ellos".80 Al utilizar el estereotipo como dispositivo de enunciación que hace visible un conjunto restringido de atributos y características del mundo delincuencial, la cinta Mala leche realiza un trabajo retórico de enclaustramiento y, con ello, se normaliza y objetiva al flaite de acuerdo con la visión de mundo, el sistema de valores y la ideología de la clase dominante. De ahí que esta cinta refuerce la hegemonía neoliberal, porque se constituye como "una forma de poder basada en el liderazgo de un grupo en muchos campos de actividad al mismo tiempo, por lo que su ascendencia demanda un consentimiento amplio y que parezca natural e inevitable". ${ }^{81}$

Hay una escena reveladora en la película de Errázuriz que muestra a Carlos y Pedro -los protagonistas de Mala Leche-, intentando asaltar alguno de los negocios nocturnos que funcionan en uno de los barrios acomodados de Santiago. En esta búsqueda por encontrar el mejor lugar para hacerse con un botín que les permita pagar la deuda que han contraído con el Llao -el narcotraficante de la población en la que viven-; de pronto toman consciencia de que ese territorio les resulta ajeno, que no saben cómo comportarse y que constituyen un otro fácilmente identificable para quienes se mueven con soltura en el sector: "Pero loco, no cacho, tenemos que pasar piola, cacha cómo andamos". ${ }^{82}$ Esta escena visibiliza el modo en que el neoliberalismo ha estructurado el imaginario de una sociedad segregada, constituida a partir de la lógica de las esferas separadas, donde la interacción entre las distintas clases sociales solo se produce por la vía de la irrupción violenta de los sujetos marginales dentro del espacio social de las clases acomodadas. Este mito invisibiliza el origen social y las condiciones de vida de buena parte de los trabajadores que diariamente circulan y habitan los barrios más acomodados, negando la posibilidad de que eventualmente pudiera existir fricción social. La irrupción del mundo marginal en estas burbujas de bienestar económico sólo se concibe como una interacción traumática producto del robo y la violencia. Es la delincuencia, entonces, la que produce el encuentro entre dos mundos socialmente distantes y, con ello, se favorece "la constitución de una sociedad dual, estructurada a dos velocidades y que coagula en un verdadero apartheid social'. ${ }^{83}$

Estas cuatro películas muestran que el cine de la transición presentó diversas representaciones fílmicas del delincuente, pero también muestran algunos elementos transversales que dicen relación con una particular forma de hacer ver y de hacer entender la delincuencia como una problemática cultural ligada a la identidad del sujeto marginal, contribuyendo así a establecer lo que Michel Foucault llama "condiciones de aceptabilidad". ${ }^{4}$ Esto es, la creación de ciertas formas de gobierno que contribuyen al cultivo de prácticas, saberes y discursos que favorecen la internalización de ciertos atributos (el pobre es peligroso), de algunas conductas sociales (el pobre es violento, es flojo), de estilos de vida (el pobre es drogadicto, alcohólico), de ciertas prácticas culturales (el pobre es ladrón, se prostituye, es mal hablado), que son asignados por un centro dominante hacia una periferia dominada, y que se consideran como constitutivos de una clase social y no de otra, y por lo tanto, son normalizados y considerados como naturales.

En el cine de la transición estos modos de ver neoliberales internalizan la subjetividad marginal como un territorio en el que cohabitan, asimétricamente, sujetos que se encuentran al margen de cualquier vínculo con el Estado, fuera de las instituciones sociales, y completamente ajenos a cualquier proyecto político, y por lo tanto, no forman parte de la modernización neoliberal. Ni siquiera se reconocen, como sugiere Mabel Moraña, "en los valores sobre los que se funda lo nacional: ni en los rasgos fundamentales de las

\footnotetext{
80 Stuart Hall, Sin garantias: trayectorias y problemáticas en estudios culturales, Bogotá: Envión Editores, 2010.

81 Ibid, p. 431.

82 Extracto tomado de la película Mala Leche.

83 Atilio Boron, "Intervención en el diálogo la trama del neoliberalismo: mercado, crisis y exclusión social”, Emir Sader y Pablo Gentili (Coord.) La trama del neoliberalismo Mercado, crisisy exclusión social, Buenos Aires: EUDEBA, 1999, p. 97.

${ }^{84}$ Michel Foucault, “¿Qué es la crítica?”, Revista de Filosofía N 11, 1995b, p. 15.
} 
identidades colectivas, ni en los valores de progreso, ni en los principios del orden, ni en las promesas siempre incumplidas de igualdad y justicia social". 85

En consecuencia, las representaciones fílmicas de la delincuencia se constituyen como tramas de sentido intertextuales en los que subyacen referencias "al funcionamiento histórico de las prácticas que se insertan en ensamblajes de poder". ${ }^{86}$ Estos ensamblajes de poder tienen que ver, en primer lugar con toda la problemática histórica y traumática de la dictadura y su posterior paso hacia una democracia semisoberana; en segundo lugar tiene que ver con la continuación del proyecto neoliberal que se anuda como una racionalidad privatizadora y privatizante, y que se impone como condición de posibilidad para el desarrollo de una democracia que debe priorizar la mercantilización de la vida social a través del consumo; y en tercer lugar tienen que ver con el modo en que la razón neoliberal se instituyó como gubernamentalidad que contribuyó en los procedimientos a través de los cuales se dirige la conducta de hombres y mujeres. Dentro de este contexto la producción cinematográfica de la transición se articula como un poder simbólico que distribuye socialmente una representación del mundo popular que asocia la pobreza a la delincuencia, la violencia y la drogadicción.

\section{Conclusiones}

Jacques Ranciére sostiene que la ficción no es sólo la creación de un mundo imaginario opuesto al real, sino que es principalmente un trabajo que debería producir un desacuerdo, es decir, la ficción como dispositivo que contribuye a tensionar aquellos modos de enunciación y representación hegemónicos y, en ese proceso de producción del disenso, admita transformar y "construir relaciones nuevas entre la apariencia y la realidad, lo singular y lo común, lo visible y su significación”. ${ }^{87}$ Ese trabajo de disenso se materializa en las películas cuando éstas logran revertir los estereotipos, transformar los clichés, o cambiar ciertas tipologías que sitúan a los sujetos como depositarios de un único discurso. En otras palabras, cuando la ficción logra articular lo que Nicolas Bourriaud llama una estética relacional que positiva en el centro de su textualidad un trabajo de coexistencia entre imagen y sociedad, entre lo visible y lo enunciable, entre el significado y el significante, que hace de la ficción una cualidad discursiva que tiene la potencia de producir "un modelo de sociedad, que traspone el ámbito de lo real o podría traducirse en él". 88

Lo que hemos podido constatar en este estudio es que la mayoría de las películas analizadas no logran elaborar una estética relacional, porque no consiguen tensionar los clichés, cambiar los estereotipos, o transformar aquellos imaginarios sociales instalados por la racionalidad neoliberal respecto de la marginalidad urbana. Estas cintas no consiguen articular un disenso que modifique sustancialmente el vínculo entre lo representado y su referente, porque son representaciones se encuentran más o menos alineadas con la subjetividad neoliberal. Su valor como objeto de análisis es precisamente que en ellas se refleja la cooptación que el neoliberalismo hace de los sistemas simbólicos que se traduce, por ejemplo, en la capacidad y el poder que tienen las industrias culturales para "adaptar y reconfigurar constantemente lo que representan; y, mediante la repetición y la selección, imponer e implantar aquellas definiciones de nosotros mismos que más fácilmente se ajusten a las descripciones de la cultura dominante". ${ }^{89}$ En tal sentido, el reduccionismo y la trivialización que el cine de la transición hace de la marginalidad social

\footnotetext{
85 Mabel Moraña, Inscripciones críticas. Ensayos sobre la cultura latinoamericana, Santiago de Chile: Editorial Cuarto Propio, 2014, p. 333.

86 Castro-Gómez, op. cit., p. 36.

87 Jacques Ranciére, El espectador emancipado, Buenos Aires: Manantial, 2010, pp. 66-67.

88 Nicolas Bourriaud, Estética relacional, Buenos Aires: Manantial, 2013, p. 139.

89 Stuart Hall, "Notas sobre la deconstrucción de 'lo popular"', Samuel Ralph (ed.) Historia popular y teoría socialista. Barcelona: Crítica, 1984, p.101.
} 
acaban por articularse como representaciones de las que se desprenden "formas gratuitas de violencia despolitizada, las cuales terminan por reforzar el mismo establishment que parecerían denunciar, al agotarse en su provocativa, inconducente y sin duda deprimente teatralidad". 90

La interpretación política que se puede hacer de la violencia urbana inscrita en algunas de las películas del período neoliberal, es que éstas emergen de una matriz neoconservadora que instala una visión despolitizada de las acciones de los marginales. En tal sentido, la violencia expuesta en estos filmes contribuye a naturalizar la violencia como singularidad, esto es, las acciones de los sujetos marginales responden más a una actuación individual que a un contexto social excluyente, desigual y que se instituye como una terrible fábrica de riqueza y de miseria. El resultado son películas que terminan generando narrativas incapaces de trascender la esfera de la vida privada, haciendo que la politización de la violencia se vuelva un imposible o, en el mejor de los casos, un asunto que no tiene mayor consecuencia. ${ }^{91}$

Se puede argumentar que las imágenes fílmicas de la violencia pueden ser leídas como la continuación de la violencia histórica que ha afectado a América Latina desde la conquista española y su macro-violencia colonialista que impuso toda una epistemología de la alfabetización y evangelización que aplastó lenguas y creencias; que siguió con la violencia del Estado-nación que instaló a la oligarquía criolla y su poder de coerción, disciplinamiento y explotación de los sectores populares; prosiguió con la violencia de la modernización capitalista a la que la siguió la violencia de las dictaduras y la violencia del neoliberalismo y su estructuración social desigual y descentrada. ${ }^{92}$

Sin duda que todas estas violencias estructurales, que se materializan cruelmente en los cuerpos de los sujetos, tienen un correlato en la violencia simbólica, que anida en las imágenes, en las palabras, en los gestos. "Convertida en producto simbólico, la representación de la violencia exhibe obscenamente la destrucción del cuerpo individual y colectivo, de la propiedad y de las redes intersubjetivas que forman 10 social. La violencia se expone como un dispositivo que despierta admiración y deseo". ${ }^{33}$ En consecuencia, la violencia simbólica inscrita en la cinematografía de la transición se configura como un correlato de la violencia objetiva, puesto que ella se inserta sobre el campo social y sobre los imaginarios, y actúa como un imperativo cultural: así son los jóvenes que habitan la periferia santiaguina, así se comportan, esos son sus modos violentos de relacionarse con los otros, así se matan entre ellos. Esto contribuye a instaurar dentro de la cinematografía nacional aquello que Ignacio Sánchez Prado llama "neomacondismo perverso", ${ }^{94}$ que se posiciona -social y culturalmente- como seña de identidad. Admitir la violencia como seña de identidad y como signo de representación de las clases populares implica hacerle el juego al neoliberalismo operante en estos discursos. Toda referencia a la violencia debería articularse como una crítica de la violencia, una comprensión de sus profundas raíces económicas, sociales y políticas. ${ }^{95}$

En consecuencia, la despolitización de la violencia significa hoy una cierta invisibilidad y banalización de la pobreza, la marginalidad y la desigualdad social, dado que sus manifestaciones -políticas y culturalesson inscritas como mercancías simbólicas que tienden a considerarse como expresiones destinadas al

\footnotetext{
90 Moraña, op. cit. p. 335.

${ }^{91}$ Ignacio Sánchez Prado, “Amores perros: violencia exótica y miedo neoliberal”, La Jiribilla. Revista digital de cultura cubana $N^{\circ}$ 25, 2006, (Versión digital).

${ }^{2}$ Moraña, op. cit.

93 Moraña, op. cit., p. 334.

94 Sánchez Prado siguiendo a Sylvia Molloy en su artículo del año 2005 "Latin America in the US Imaginary: Postcolonialism, Translation and the Magic Realist Imperative", plantea que el dominio del realismo-mágico en su vertiente neoliberal ha sido resignificado por el imperativo de la violencia como dispositivo identitario de lo popular latinoamericano, el cual se configura como una suerte de neomacondismo perverso que rearticula el discurso civilización o barbarie "conforme los espectadores metropolitanos empiezan a pensar una otredad fundada en la violencia. Los placeres del trópico vienen aderezados con el exotismo de la miseria" (Sánchez Prado, op. cit.).

${ }^{55}$ Sánchez Prado, op. cit.
} 
consumo y la entretención de las clases medias y altas de la sociedad chilena. La mercantilización y la despolitización de la vida marginal en las películas analizadas son indicadores de la perdida de importancia en la que ha caído la esfera pública como espacio de deliberación y elucidación de la comunidad de individuos. En esa situación límite, se legitima socialmente el mito neoliberal que hace de las prácticas culturales ligadas a las clases populares un asunto de la naturaleza humana, de modo que el neoliberalismo opera, entonces, como la civilización de los deseos autorregulados y naturalizados en la sociedad de consumo.

En suma, los procesos de producción de la subjetividad delincuencial que se desprenden del cine de la transición muestran una tendencia a naturalizar la marginalidad social como una problemática ligada al individuo como entidad autónoma, donde cada uno de los sujetos ocupa un lugar predeterminado de acuerdo con el sitio que le corresponde en función de su clase, género, etnia, etc. Se trata, por lo tanto, de representaciones que tienden a tachar o borrar aquellas problemáticas sociopolíticas ligadas a la marginalidad y la delincuencia, e instalan en su lugar un orden discursivo que elimina, ciertamente, no la violencia, la drogadicción, la precariedad y la miseria asociada al mundo marginal-delincuencial (por el contrario, es eso lo que se busca mostrar), sino su contingencia, su cualidad sociológica e histórica. Las películas que hemos analizado muestran la delincuencia y los actos vinculados a ella escenificados bajo una mirada que exalta aquellos aspectos espectaculares de la vida marginal y, con ello "les confiere una claridad que no es la de la explicación, sino de la comprobación". ${ }^{96}$ A través de la representación, las películas corroboran y naturalizan el imaginario que vincula a los jóvenes que habitan la periferia santiaguina con la delincuencia, la drogadicción y la violencia sin plantear ningún tipo de cuestionamiento acerca de esta realidad social. De modo que se lleva a cabo una operación de ex-nominacio $\square$ n, esto es, se cancela o anula la complejidad de la vida marginal, y en su lugar se construyen representaciones que muestran un mundo sin contradicciones, sin causalidades, que despliegan imágenes y sonidos que parecen sustentados en las evidencias, donde las cosas parecen significar por sí mismas.

\section{Bibliografía}

Acevedo Moya, Juan Pablo. "Crimen y castigo en el Chile democrático: la derecha y la seguridad ciudadana en los noventa. 1990-1994". Revista Divergencia N 7, 2016, pp. 65-78.

Araujo, Kathya. El miedo a los subordinados. Una teoría de la autoridad. Santiago de Chile: LOM Ediciones, 2016.

Araujo, Kathya y Martuccelli, Danilo. Desafíos comunes. Retrato de la sociedad chilena y sus individuos, Tomo 1. Santiago de Chile: LOM Ediciones, 2012.

Barthes, Roland. Mitologias. Buenos Aires: Siglo XXI Editores, 2012.

Variaciones sobre la escritura. Barcelona: Paidós, 2002.

S/Z. Madrid: Sigo Veintiuno Editores, 2001a.

"El problema de la significación en el cine". En La torre Eiffel. Textos sobre la imagen. Barcelona: Paidós, 2001b, pp. 27-34.

${ }^{96}$ Roland Barthes, Mitologías. Buenos Aires: Siglo XXI Editores, 2012, p. 239. 
"La Guerra de los lenguajes". En El susurro del lenguaje. más allá de la palabra y la escritura. Barcelona: Paidós, 1987, pp. 135-139.

"Escritores, intelectuales, profesores". En Lo obvio y lo obtuso. Imágenes, gestos, voces. Barcelona: Paidós, 1986, pp. 313-336.

Baudrillard, Jean. El intercambio imposible, Madrid: Cátedra, 2000.

Boron, Atilio. "Intervención en el diálogo la trama del neoliberalismo: mercado, crisis y exclusión social". En Emir Sader y Pablo Gentili (Coord.) La trama del neoliberalismo Mercado, crisis y exclusión social. Buenos Aires: EUDEBA, 1999, pp. 91-128.

Bourdieu, Pierre. 2006. "Sobre el poder simbólico". En Intelectuales, política y poder. Buenos Aires: EUDEBA, pp. 65-73.

La distinción. Criterios y bases sociales del gusto. México: Taurus.

Bourriaud, Nicolas. Estética relacional. Buenos Aires: Manantial, 2013.

Brunner, José Joaquín. Apuntes sobre la figura cultural del pobre. Documento de trabajo $N^{\circ} 69 / 78$. Santiago de Chile: FLACSO, 1978.

Brown, Wendy. El pueblo sin atributos. La secreta revolución del neoliberalismo. Barcelona: Malpaso Ediciones, 2017.

Castells, Manuel. Globalización, desarrollo y democracia: Chile en el contexto mundial. Santiago de Chile: Fondo de Cultura Económica, 2006.

Castro-Gómez, Santiago. Historia de la gubernamentalidad I. Razón de Estado, liberalismo y neoliberalismo en Michel Foucault. Bogotá: Siglo del Hombre Editores, 2015.

Cavallo, Ascanio, Douzet, Pablo y Rodríguez, Cecilia. Huérfanos y perdidos. El cine chileno de la transición. Santiago de Chile: Grijalbo, 1999.

Cooper, Doris. Delincuencia y desviación juvenil, Santiago de Chile: LOM Ediciones, 2005.

"Delincuencia urbana femenina en Chile: una delincuencia que se moderniza", Revista de Derecho, Criminología y Ciencias penales, No 1, 1999, pp. 179, 184.

Delincuencia común en Chile. Santiago de Chile: LOM Ediciones, 1994.

147.

“Teoría del continuo subcultural de la delincuencia” Revista de Sociología No 4, 1989, pp. 115-

Corro, Pablo. Retóricas del cine chileno. Ensayos con realismo. Santiago de Chile: Editorial Cuarto Propio, 2012.

Debord, Guy. La sociedad del espectáculo. Valencia, Pre-textos, 2007.

Deleuze, Gilles. Foucault. Barcelona: Paidós, 1987. 
Deleuze, Gilles y Guattari, Félix. El Anti Edipo. Capitalismo y esquizofrenia. Barcelona: Paidós, 1998.

Didi-Huberman, Georges. Pueblos expuestos. Pueblos figurantes. Buenos Aires: Manantial, 2014.

Fassin, Dodier. "Otra política de la vida es posible: crítica antropológica del biopoder", Vanessa Lemm (editora) Michel Foucault: neoliberalismo y biopolitica. Santiago de Chile: Ediciones Universidad Diego Portales, 2010, pp. 21-49.

Esposito, Roberto. Bíos. Biopolítica y filosofía. Buenos Aires: Amorrortu Ediciones, 2011.

Fassin, Dodier. "Otra política de la vida es posible: crítica antropológica del biopoder". En Vanessa Lemm (editora) Michel Foucault: neoliberalismo y biopolitica. Santiago de Chile: Ediciones Universidad Diego Portales, 2010, pp. 21-49.

Follegati, Luna y Karmy, Rodrigo. “Introducción”. En Luna Follegate y Rodrigo Karmy (comp.) Estudios en Gubernamentalidad. Ensayos sobre poder, vida y neoliberalismo. Viña del Mar: Asociación Comunes, 2018, pp. $17-45$.

Foucault, Michel. Nacimiento de la biopolítica. Buenos Aires: Fondo de Cultura Económica, 2016.

Seguridad, territorio y población. Buenos Aires: Fondo de Cultura Económica, 2006.

Defender la sociedad. Buenos Aires: Fondo de Cultura Económica, 2000.

$1995 \mathrm{a}$.

Las palabras y las cosas. Una arqueología de las ciencias humanas. México DF: Siglo XXI Editores, “¿Qué es la crítica?”, en Revista de Filosofía N 11, 1995b, pp. 5-25.

Garland, David. La cultura del control. Crimen y orden social en la sociedad contemporánea. Barcelona: Gedisa, 2012.

Hall, Stuart. Sin garantias: trayectorias y problemáticas en estudios culturales. Bogotá: Envión Editores, 2010.

"Notas sobre la deconstrucción de "lo popular" en Samuel Ralph (ed.) Historia popular y teoría socialista. Barcelona: Crítica, 1984, pp. 93-110,

Huneeus, Carlos. La democracia semisoberana. Chile después de Pinochet. Santiago de Chile: Taurus, 2014.

Jameson, Fredric. La estética geopolitica: cine y espacio en el sistema mundial. Barcelona: Paidós, 1995.

Jofré, René. "Seguridad Ciudadana y estrategias de Comunicación en Chile", en Elisabet Gerber (ed.) Políticas de Seguridad Ciudadana. La agenda ausente en el Cono sur. Santiago de Chile: Centro de Competencia en Comunicación para América Latina y Friedrich Ebert Stiftung, 2006, pp. 77-88.

Marx, Karl y Engels, Friedrich. La ideología alemana. Barcelona: Ediciones Grijalbo, 1974. 
Molloy, Silvia. "Latin America in the US Imaginary: Postcolonialism, Translation and the Magic Realist Imperative", en Mabel Moraña (ed.) Ideologies of Hispanism. Nashville: Vanderbilt University Press, 2005.pp. 189-200.

Moraña, Mabel. Inscripciones críticas. Ensayos sobre la cultura latinoamericana. Santiago de Chile: Editorial Cuarto Propio, 2014.

Moulian, Tomás. El consumo me consume. Santiago de Chile: LOM Ediciones, 1998. Chile Actual. Anatomía de un mito. Santiago de Chile: LOM Ediciones, 1997.

Peña, Carlos. Lo que el dinero si puede comprar. Santiago de Chile: Taurus, 2017.

Pincheira, Iván. "El Gobierno del miedo". En Luna Follegati y Rodrigo Karmy (comp.) Estudios en Gubernamentalidad. Ensayos sobre poder, vida y neoliberalismo. Viña del Mar: Asociación Comunes, 2018, pp. 231-280.

Ramos, Marcela y Guzmán, Juan Andrés. La guerra y la paz, ciudadana, Santiago de Chile: LOM Ediciones, 2000.

Ranciére, Jacques. El espectador emancipado. Buenos Aires: Manantial, 2010.

Richard, Nelly. Latencias y sobresaltos de la memoria inconclusa (Chile: 1990-2015). Buenos Aires: EDUVIM, 2017.

Rojas, Darío. "Flaite: algunos apuntes etimológicos", en Alpha. Revista de artes, letras y filosofía No 40, 2015, pp. 193-200.

Sánchez Prado, Ignacio. "Amores perros: violencia exótica y miedo neoliberal”. En La Jiribilla. Revista digital de cultura cubana $N^{\circ}$ 25, 2006, disponible en: http://www.lajiribilla.cu/2006/n251 02/251 03.html (Consultada el 20 de septiembre de 2018).

Sandel. Michel. Lo que el dinero no puede comprar. Los limites morales del mercado. Buenos Aires: Debate, 2013.

Senellart, Michel. "Situación del curso". En Seguridad, territorio y población. Buenos Aires: Fondo de Cultura Económica, 2006,

Tironi, Eugenio, Cuánto y cómo cambiamos los chilenos. Balance de una década. Censos 1992-2002. Santiago de Chile: INE, 2003. 